\title{
Effectiveness Measurement of Digital Library in Higher Education
}

\author{
Rabab Dawoud Alsaffar \\ Associate Professor \\ The Public Authority for Applied Education and Training \\ College of basic education, Kuwait \\ Rd.alsaffar@paaet.edu.kw \\ Husian F. Ghuloum \\ Associate Professor \\ Department of Library and Information Science, \\ in Public Authority for Applied Education and Training \\ .hf.ghuloum@paaet.edu.kw \\ Zuwainah Al-lamki \\ Assistant Professor \\ Department of Library and Information Science, \\ in Public Authority for Applied Education and Training. \\ z.allamki@paaet.edu.kw
}

\begin{abstract}
The purpose of this research is to fill the gap between the student expectation and service provided by the digital library in terms of the service quality offering in the library. The user satisfaction of digital library was measured quantitatively through online questionnaire and analysed to establish relationship between the user satisfaction and its antecedents in order to identify critical factors so that suggestions could be made for the Chief Information Officers to enhance the user satisfaction.

Keywords: Technology acceptance model, Perceived ease of use, Perceived usefulness, Intention to use, User satisfaction, Digital library.

DOI: $10.7176 / \mathrm{IKM} / 12-2-03$

Publication date: February $28^{\text {th }} 2022$

\section{INTRODUCTION}

Technology Acceptance Model (TAM) (Davis, 1989) was proposed is late 80s and since then it has been integrated with other models as well as extended to fit into many different contexts of technology usage which includes online shopping (Klopping \& McKinney, 2004), E-commerce Valencia et al., (2019), E-payments (Ardiansah et al., 2020), mobile libraries (Rafique et al., 2020), ride-sharing services (Wang et al., 2020). Since its inception the TAM has been integrated with other models which include: Theory of Planned Behaviour (TRA) (Ajzen, 2015); Diffusion of Innovations Theory (Dearing \& Cox, 2018); Uses and Gratification Theory (Korhan \& Ersoy, 2016), Unified Theory of Acceptance and Use of Technology (Venkatesh et al., 2016), This process of integration and extension of TAM is still on as various newer technologies are emerging out in the ever changing global scenario and accordingly newer variables are being added.

There is also evidence for the application of TAM in educational context in terms of various technologies. Fathema et al., (2015) investigated factors that affect faculty members' Learning Management System (LMS) usage behaviour, focusing on user related variables and their pivotal role in determining faculty attitudes toward LMSs. Data were obtained from 560 faculty members (from two universities) and analysed using Structural Equation Modelling (SEM). The study results revealed that the three proposed external variables: system quality; perceived self-efficacy and facilitations conditions were significant predictors of faculty attitude towards LMSs. Similar to prior research findings, the study results further confirmed the validity of the extended TAM in determining users' technology acceptance behaviour.

Chintalapati \& Daruri (2017) tested the relationship between the user attitude, perceived usefulness, perceived ease of use, and behavioural intention in the context of YouTube usage for learning purposes in higher education. The sample size was 200 with 142 respondents were from management studies, 33 from science and technology and remaining from humanities and social sciences. The study indicated that all the variables considered had a significant and positive relationship with the behavioural intention to use the technology.

Martín - García et al., (2019) tested the TAM in the context of adoption of blended learning in higher education by application of data mining techniques. The sample included 980 active academic staff from 43 Spanish public universities. The results indicated that the intention to use blended learning was the most important
\end{abstract}


predictor variable, the relationship between higher frequency of use and experience in digital educational environments with higher stages of implementation was verified, however, socio-demographic variables had marginal effect on TAM variables.

While all these aforementioned theoretical models and specific studies in the context of higher education have added immensely to the body of knowledge in the integration of technology component and human element component in learning, a gap still lies in the accounting for the quality and user acceptance aspects of the TAM, which are quintessential in the context of testing the effectiveness of technology used in digital library. To fill the observed gap in the literature, this research considers the integration of the three quality components as the antecedents to the TAM, namely - information quality, system quality and service quality, and also, user satisfaction as the outcome. The conceptualized model needs to be empirically validated and the following are the objectives of research:

- Theorize an Extended Technology Acceptance Model (ETAM) in the context of digital library technology in higher education.

- Empirically test the ETAM for the significance of interrelationships between its dimensions.

- Draw theoretical and practical implications for the benefit of Chief Information Managers of multimediabased learning in enhancing the effectiveness of learning.

\section{THE HYPOTHETICAL MODEL}

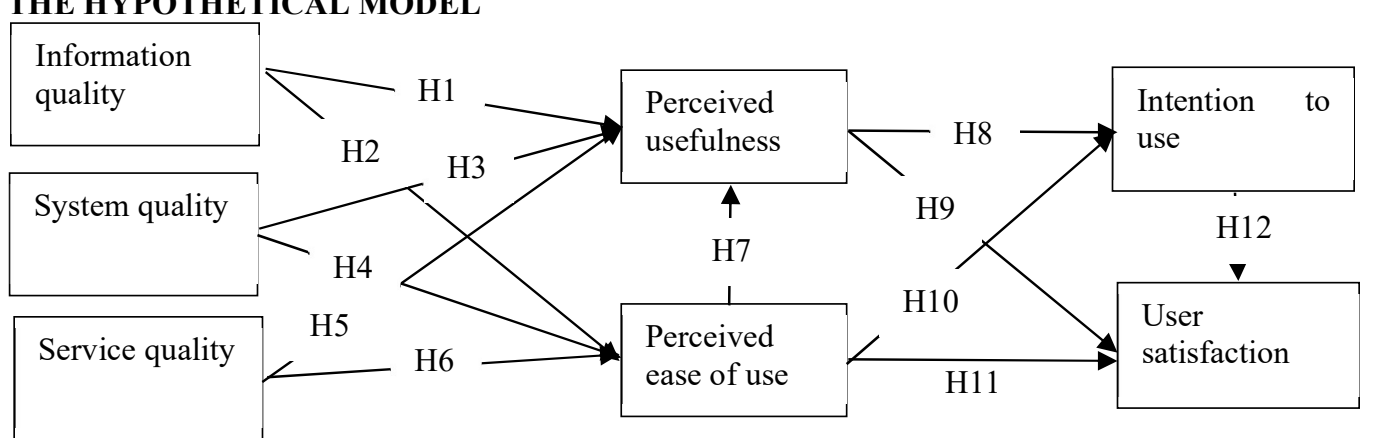

Figure 1: The Hypothetical Model

The Integrated Technology Acceptance Model (ITAM) (Figure 1) has been hypothesized using the research findings of several researchers in various technological contexts such as e-learning, online purchase, mobile banking, e-medicine, virtual-learning, social networking etc. The main missing element in the ITAM is the quality dimensions and user satisfaction, as discusses in the previous section, and integrating these two with TAM would be of great significance, particularly in the context of digital library in HE. There are several research studies which have formed the basis for the building of the ITAM and are discussed in the following sections.

Linkage of Information Quality with Perceived Ease of Use and Perceived Usefulness

Several researchers have linked the information quality (INF) to perceived ease-of-use (PEU) (e.g., Almahamid et al., 2010; Pitafi et al., 2020; Rahmi, 2018; Venkatesh, 2010) and perceived usefulness (PRU) (e.g., Fadelelmoula, 2018; Kang \& Namkung, 2019; Oliveira et al., 2020). These studies are in various contexts of technology use such as educational technology, multi-media technology, online technology etc. There are not many studies which have explored the significance of relationship between these variables in the context of digital library usage and hence the following hypotheses have been postulated.

$\mathrm{H}_{1}$ : There is a positive significant impact of information quality on perceived usefulness of the digital library usage in higher education.

$\mathrm{H}_{2}$ : There is a positive significant impact of information quality on perceived ease-of-use of the digital library usage in higher education.

Linkage of System Quality with Perceived Ease of Use and Perceived Usefulness

Several researchers have linked the system quality (SYQ) to perceived ease-of-use (PEU) (e.g., Keni, 2020; Saadé \& Bahli, 2005; Tahar et al., 2020) and perceived usefulness (PRU) (e.g., Andarwati et al., 2020; Mican et al., 2020; Normelindasari \& Solichin, 2020;). These studies are in various contexts of technology use such as marketing technology, mobile-library technology, ERP technology etc. There are not many studies which have explored the significance of relationship between these variables in the context of digital library usage and hence the following hypotheses have been postulated.

$\mathrm{H}_{3}$ : There is a positive significant impact of system quality on perceived usefulness of the digital library usage in higher education.

$\mathrm{H}_{4}$ : There is a positive significant impact of system quality on perceived ease-of-use of the digital library usage in higher education.

Linkage of Service Quality with Perceived Ease-of-use and Perceived Usefulness 
Several researchers have linked the service quality (SVQ) to perceived ease-of-use (PEU) (e.g., Arta \& Azizah, 2020; Daryanto, 2019; Keni, 2020) and perceived usefulness (PRU) (e.g., Keni, 2020; Chen \& Aklikokou, 2020; Kurniasari et al., 2020). These studies are in various contexts of technology use such as e-governance technology, ICT usage, mobile health technology etc. There are not many studies which have explored the significance of relationship between these variables in the context of digital library usage and hence the following hypotheses have been postulated.

$\mathrm{H}_{5}$ : There is a positive significant impact of service quality on perceived usefulness of the digital library usage in higher education.

$\mathrm{H}_{6}$ : There is a positive significant impact of service quality on perceived ease-of-use of the digital library usage in higher education.

Linkage of Perceived Ease-of-use with Perceived usefulness

Several researchers have linked the PEU to PRU (e.g., Caffaro et al., 2020; Chen \& Aklikokou, 2020; Iriani \& Andjarwati, 2020; Winata et al., 2020). These studies are in various contexts of technology use such as e-commerce technology, augmented reality technology, educational technology etc. There are not many studies which have explored the significance of relationship between these variables in the context of digital library usage and hence the following hypotheses have been postulated.

$\mathrm{H}_{7}$ : There is a positive significant impact of perceived ease-of-use on perceived usefulness of the digital library usage in higher education.

Linkage of Intention to use and User satisfaction

Several researchers have linked the PRU with intention to use (INU) (e.g.,) and user satisfaction (USS) (e.g., Keni, 2020; Chen \& Aklikokou, 2020; Kim \& Lee, 2014; Kurniasari et al., 2020). These studies are in various contexts of technology use such as e-governance technology, ICT usage, mobile health technology etc. There are not many studies which have explored the significance of relationship between these variables in the context of digital library usage and hence the following hypotheses have been postulated.

$\mathrm{H}_{8}$ : There is a positive significant impact of perceived ease-of-use on intention to use the digital library usage in higher education.

$\mathrm{H}_{9}$ : There is a positive significant impact of service quality on perceived ease-of-use of the digital library usage in higher education.

Linkage of Perceived ease of use with Intention to use and User satisfaction

Several researchers have linked the PEU with intention to use (INU) (e.g., Almahamid et al., 2010; Fagan et al., 2008; Rawashdeh, 2021). There are also research studies which have linked PEU to user satisfaction (USS) (e.g., Bradley \& Lee, 2007; Calisir \& Calisir, 2014; Rawashdeh, 2021). These studies are in various contexts of technology use such as training, education, tourism, hospitality etc. There are not many studies which have explored the significance of relationship between these variables in the context of digital library usage and hence the following hypotheses have been postulated.

$\mathrm{H}_{10}$ : There is a positive significant impact of perceived ease-of-use on intention to use the digital library usage in higher education.

$\mathrm{H}_{11}$ : There is a positive significant impact of perceived ease-of-use on user satisfaction of the digital library usage in higher education.

\section{RESEARCH METHODOLOGY}

\section{Research Design}

This research is based on positivist paradigm with quantitative approach and the type of study is exploratory in nature. Questionnaire survey is the method used in the research design. The sample frame comprises the students in higher education in The Public Authority for Applied Education and Training in Kuwait. Ethical permission for the survey was taken from the Heads of the institutes. Voluntary participation of the respondents in the survey through Google Forms has been administered and confidentiality statement in the questionnaire has ensured the unbiased response to the questions. Google Forms were available both in English and Arabic language to the respondents to suit to their convenience. Convenience sampling has been used as the sampling method. Structural Equation Modelling (SEM) technique has been adopted to carry out the quantitative analysis of the data. SEM has been specifically chosen as it can perform both regression and factor analysis simultaneously.

\section{Sample Design}

The convenience sampling which is a non-probability based sampling technique is widely used in this kind of research and the recommendation is to use at least five times the manifest variables of study to make the sample adequate (Tjiu \& Purwanto, 2017). As each of the seven manifest variable had three items a sample size of 211 stands justified. The sample frame is the students in Public Authority in Applied Education and Training and Kuwait university both located in Kuwait. These two colleges have been specifically chosen as they represent the students using digital library in Kuwait. Students were emailed the link of the Google form having the selfadministered questionnaire and 211 usable filled questionnaires were obtained (response rate $38 \%$ ). 


\section{Questionnaire Development}

The self-administered questionnaire was consisted of two parts: 1. the demographic information of the respondents (gender, age, and qualification), and 2. the quantitative data collection items on the Likert 5-point scale (5- strongly agree; 1 - Strongly disagree). The items used in the questionnaire were derivatives of standard scales developed by researchers and were used by researchers in many different contexts such as educational technology, mobilelearning, healthcare technologies, online purchase, etc. These scales had proved validity and reliability; however, as they were modified to suit to the context of digital library some of the items were slightly modified. To ensure that these modifications do not affect reliability and validity measures, Confirmatory Factor Analysis (CFA) has been carried out using a pilot sample of 40 students who were not the part of primary data collection. The dimensions, contributing authors, description and the sample item are given in the Table 1 . The questionnaire used in this research is attached in Appendix 1.

Table 1: Dimension, contributing authors, description, sample item

\begin{tabular}{|c|c|c|c|}
\hline Dimension & Contributing authors & Explanation & Sample item \\
\hline $\begin{array}{l}\text { 1. Information } \\
\text { quality }\end{array}$ & $\begin{array}{l}\text { Hanjaya et al., (2019); Kang } \\
\text { \& Namkung (2019); Kim et } \\
\text { al., (2004); Rita et al., (2019); } \\
\text { Wang \& Li, (2019). }\end{array}$ & $\begin{array}{l}\text { It is the degree to which } \\
\text { the system/technology } \\
\text { communicates effectively } \\
\text { to provide clear } \\
\text { information for its use. }\end{array}$ & $\begin{array}{l}\text { The information on the digital } \\
\text { library usage portal is pretty } \\
\text { much what I need to carry out } \\
\text { my tasks in searching for the } \\
\text { articles/books/conference } \\
\text { proceedings. }\end{array}$ \\
\hline $\begin{array}{l}\text { 2. } \\
\text { System } \\
\text { quality }\end{array}$ & $\begin{array}{l}\text { Hanjaya et al., (2019); Lee et } \\
\text { al., (2019); Liu \& } \\
\text { Napitupulu, } \quad(2020) \text {; } \\
\text { McKinney et al., (2002). }\end{array}$ & $\begin{array}{l}\text { It is the degree to which a } \\
\text { technology provides a } \\
\text { better usage experience. }\end{array}$ & $\begin{array}{l}\text { Digital library systems are } \\
\text { reliable in terms of my usage. }\end{array}$ \\
\hline $\begin{array}{ll}\text { 3. } & \text { Service } \\
\text { quality }\end{array}$ & $\begin{array}{l}\text { Boyer \& Frohlich, (2009); } \\
\text { Hanjaya et al., (2019); Chi } \\
(2018) \text {; Al-Fraihat et al., } \\
(2020)\end{array}$ & $\begin{array}{l}\text { It is the degree to which } \\
\text { the technology provides } \\
\text { the desired assistance } \\
\text { during and post usage. }\end{array}$ & $\begin{array}{l}\text { My service needs in terms of } \\
\text { digital library usage is well } \\
\text { understood. }\end{array}$ \\
\hline $\begin{array}{ll}\text { 4. } & \text { Perceived } \\
\text { ease of use }\end{array}$ & $\begin{array}{l}\text { Akar (2019); Al-Okaily et } \\
\text { al., (2020); Wang \& Li, } \\
\text { (2019); Ameen et al., (2019); } \\
\text { Lavidas et al., (2019); Lee \& } \\
\text { Kim, (2009); Lin, (2006); } \\
\text { Suki et al., (2011) }\end{array}$ & $\begin{array}{l}\text { It is the degree to which } \\
\text { the use of the system is } \\
\text { considered to be } \\
\text { effortless. }\end{array}$ & $\begin{array}{l}\text { Learning to operate the } \\
\text { multimedia used in the } \\
\text { education system would be } \\
\text { easy for me. }\end{array}$ \\
\hline $\begin{array}{ll}\text { 5. } & \text { Perceived } \\
\text { usefulness }\end{array}$ & $\begin{array}{l}\text { Alsabawy et al., (2016); } \\
\text { Danurdoro \& Wulandari, } \\
(2016) ; \quad \text { Dobricki et al., } \\
(2021) ; \quad \text { Elkaseh et al., } \\
\text { (2016); Hamid et al., (2016); } \\
\text { Ismail (2016); Ruggieri et al., } \\
(2021) \text {. }\end{array}$ & $\begin{array}{l}\text { It is the degree to which } \\
\text { learning } \\
\text { system/technology would } \\
\text { enhance the task } \\
\text { performance. }\end{array}$ & $\begin{array}{l}\text { Using multimedia in learning } \\
\text { will improve my academic } \\
\text { performance. }\end{array}$ \\
\hline $\begin{array}{ll}\text { 6. Intention to } \\
\text { use }\end{array}$ & $\begin{array}{l}\text { Abdullah et al., (2016); Al- } \\
\text { Okaily et al., (2020); Pozón- } \\
\text { López et al., (2020); Wan \& } \\
\text { Shen, (2015); Wicaksono \& } \\
\text { Maharani, (2020). }\end{array}$ & $\begin{array}{l}\text { It is the strength of the } \\
\text { desire to use a } \\
\text { system/technology. }\end{array}$ & $\begin{array}{l}\text { I intend to use multimedia in } \\
\text { learning. }\end{array}$ \\
\hline $\begin{array}{ll}\text { 7. User } \\
\text { satisfaction }\end{array}$ & $\begin{array}{l}\text { Walsh \& Beatty (2007); Rita } \\
\text { et al., (2019); Japutra et al., } \\
(2021) \text {; Alyoussef (2021); } \\
\text { Kim et al., (2004) }\end{array}$ & $\begin{array}{l}\text { It is the degree to which } \\
\text { the user is satisfied with } \\
\text { the system/ technology. }\end{array}$ & $\begin{array}{l}\text { I am satisfied with the services } \\
\text { offered by digital library. }\end{array}$ \\
\hline
\end{tabular}

\section{ANALYSIS AND DISCUSSION}

\section{Measurement Model}

In Structural Equation Modelling (SEM) the measurement model (Figure 2) deals with the reliability and validity aspects of the model. The Cronbach's alpha (coefficient), which is the measure of reliability of the data, has the acceptable value ranging from 0.6 to 0.9 (Table 2), except one manifest variable which has a factor loading of 0.4 . According to the principles of SEM only 2 manifest variables are adequate to perform the analysis and the remaining two have a factor loading of 0.7 ad 0.8 indicating a high level of internal consistency (Cut off $=0.6$; Ahmad, Zulkurnain \& Khairushalimi, 2016). This indicator has been retained intentionally as it was an important measure (Item - The information on the digital library usage portal is pretty much what I need to carry out my 
tasks in searching for the articles/books/conference proceedings). Another widely used measurement of reliability is the composite reliability estimate which is ranging from 0.8 to 0.9 indicating moderate to high reliability values (Munir, 2018). The factor loading gives the convergent validity and the values above 0.6 indicate an acceptable effect of the factors (Hair, Ringle \& Sarstedt, 2012) on the dimensions they represent (Table 3). The final test is the discriminant validity, which is a measure of validity of the instrument used for measurement, and to ensure this the square root of average variance extracted (AVE) of a construct was compared with the correlation of the construct with the remaining constructs. It is found that all square roots of AVE of all the constructs are greater than the correlation values of the construct with the other constructs; hence, ensures that the instrument has the desired validity (Table 4). Further, the $\mathrm{R}^{2}$ values of the endogenous variables is a measure of the goodness of the model fit. In the present case the $\mathrm{R}^{2}$ values range from 0.4 to 0.7 , which indicates that the endogenous variables explain 40 to $70 \%$ of the variances observed in the analysis. In other words, $40-70 \%$ of the influences of the independent variables on the dependent variables is explained through the model. Cut-off value of $\mathrm{R}^{2}$ value is 0.1 (Bolt et al., 2018), and hence the model fit is adequate.

Table 2: Reliability and Validity

\begin{tabular}{|l|r|r|r|r|}
\hline & Cronbach's Alpha & \multicolumn{1}{|l|}{ rho_A } & Composite Reliability & Average Variance Extracted (AVE) \\
\hline INFQ & 0.85 & 0.93 & 0.91 & 0.77 \\
\hline INU & 0.82 & 0.83 & 0.89 & 0.74 \\
\hline PEU & 0.85 & 0.87 & 0.91 & 0.77 \\
\hline PRU & 0.67 & 0.67 & 0.82 & 0.60 \\
\hline SVQ & 0.83 & 0.85 & 0.90 & 0.74 \\
\hline SYQ & 0.62 & 0.67 & 0.80 & 0.58 \\
\hline USS & 0.86 & 0.87 & 0.92 & 0.79 \\
\hline
\end{tabular}

Legend:

$\mathrm{INF}=$ Information Quality; INU = Intention to Use; PEU = Perceived Ease of Use

$\mathrm{PRU}=$ Perceived Usefulness; SVQ = Service Quality; SYQ = System Quality

USS $=$ User Satisfaction

Table 3: Factor Loadings

\begin{tabular}{|c|c|c|c|c|c|c|c|}
\hline & INFQ & INU & PEU & PRU & SVQ & SYQ & USS \\
\hline INF1 & 0.39 & & & & & & \\
\hline INF2 & 0.69 & & & & & & \\
\hline INF3 & 0.76 & & & & & & \\
\hline INU1 & & 0.73 & & & & & \\
\hline INU2 & & 0.81 & & & & & \\
\hline INU3 & & 0.80 & & & & & \\
\hline PEU1 & & & 0.90 & & & & \\
\hline PEU2 & & & 0.81 & & & & \\
\hline PEU3 & & & 0.88 & & & & \\
\hline PRU1 & & & & 0.76 & & & \\
\hline PRU2 & & & & 0.69 & & & \\
\hline PRU3 & & & & 0.71 & & & \\
\hline SVQ1 & & & & & 0.90 & & \\
\hline SVQ2 & & & & & 0.91 & & \\
\hline SVQ3 & & & & & 0.87 & & \\
\hline SYQ1 & & & & & & 0.73 & \\
\hline SYQ2 & & & & & & 0.85 & \\
\hline SYQ3 & & & & & & 0.80 & \\
\hline USS1 & & & & & & & 0.85 \\
\hline USS2 & & & & & & & 0.89 \\
\hline USS3 & & & & & & & 0.91 \\
\hline
\end{tabular}


Table 4: Discriminant validity

\begin{tabular}{|l|r|r|r|r|r|r|l|}
\hline & \multicolumn{1}{|l|}{ INFQ } & INU & PEU & PRU & SVQ & SYQ & USS \\
\hline INFQ & $\mathbf{0 . 8 8}$ & & & & & & \\
\hline INU & 0.48 & $\mathbf{0 . 8 6}$ & & & & & \\
\hline PEU & 0.62 & 0.66 & $\mathbf{0 . 8 8}$ & & & & \\
\hline PRU & 0.49 & 0.58 & 0.79 & $\mathbf{0 . 7 8}$ & & & \\
\hline SVQ & 0.48 & 0.45 & 0.48 & 0.61 & $\mathbf{0 . 8 6}$ & & \\
\hline SYQ & 0.71 & 0.47 & 0.70 & 0.72 & 0.64 & $\mathbf{0 . 7 6}$ & \\
\hline USS & 0.51 & 0.76 & 0.73 & 0.69 & 0.60 & 0.67 & $\mathbf{0 . 8 9}$ \\
\hline
\end{tabular}

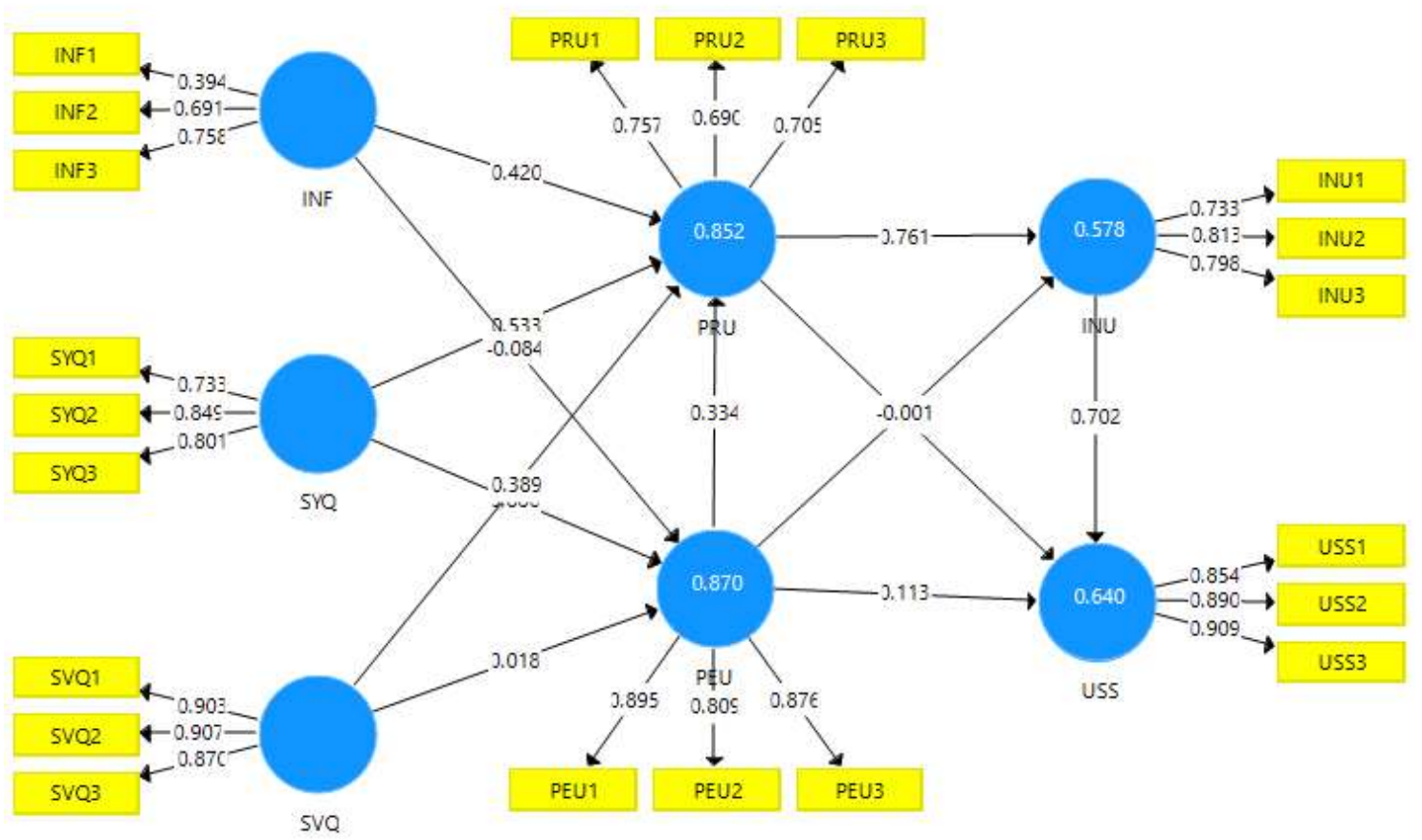

Figure 2: Measurement Model

Legend:

INF = Information Quality; INU = Intention to Use; PEU = Perceived Ease of Use

PRU = Perceived Usefulness; SVQ = Service Quality; SYQ = System Quality

USS $=$ User Satisfaction

\section{Structural Model}

The structural model (Figure 3) provides the results of the hypothesis testing (Table 5). In this research there were 12 direct hypotheses, which were tested with respect to the user satisfaction with the digital library in Higher Education. Among the 12 hypotheses being tested, six were supported and the rest were rejected. Following are the hypotheses which have been supported.

$\mathrm{H}_{1}$ : There is a positive significant impact of information quality on perceived usefulness of the digital library usage in higher education. 


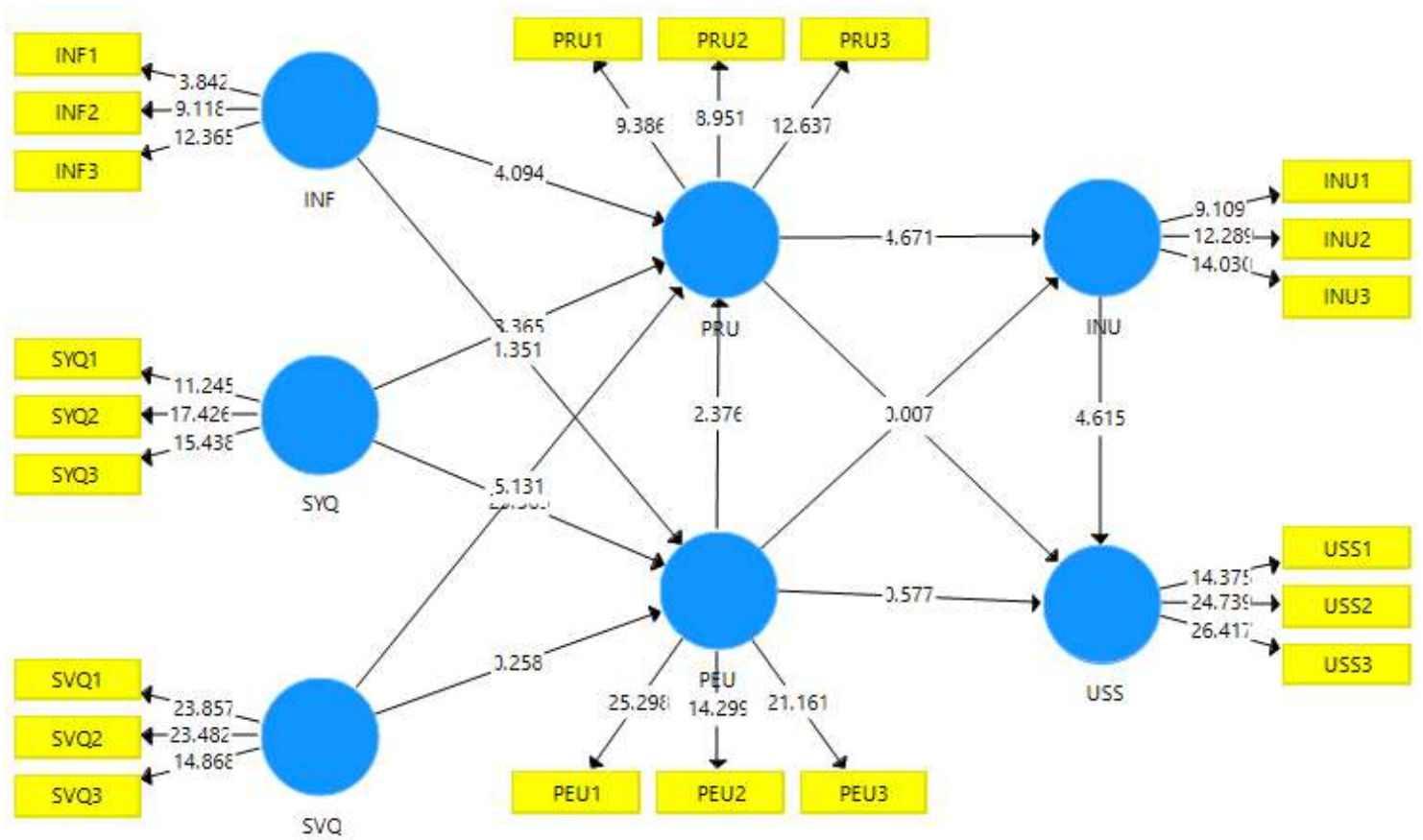

Figure 3: Structural Model

Table 5: Results of Hypothesis Testing

\begin{tabular}{|l|l|l|l|l|l|l|}
\hline & $\begin{array}{l}\text { Original } \\
\text { Sample } \\
(\mathrm{O})\end{array}$ & $\begin{array}{l}\text { Sample } \\
\text { Mean } \\
(\mathrm{M})\end{array}$ & $\begin{array}{l}\text { Standard } \\
\text { Deviation } \\
(\text { STDEV })\end{array}$ & $\begin{array}{l}\text { T Statistics } \\
(\mid \mathrm{O} / \text { STDEV })\end{array}$ & P Values & \\
\hline INF - > PEU & -0.08 & -0.08 & 0.06 & 1.35 & 0.18 & Not supported \\
\hline INF - > PRU & 0.42 & 0.42 & 0.10 & 4.09 & 0.00 & Supported \\
\hline INU -> USS & 0.70 & 0.69 & 0.15 & 4.62 & 0.00 & Supported \\
\hline PEU -> INU & 0.00 & -0.01 & 0.19 & 0.01 & 1.00 & Not supported \\
\hline PEU -> PRU & 0.33 & 0.33 & 0.14 & 2.38 & 0.02 & Supported \\
\hline PEU -> USS & 0.11 & 0.14 & 0.20 & 0.58 & 0.56 & Not supported \\
\hline PRU -> INU & 0.76 & 0.77 & 0.16 & 4.67 & 0.00 & Supported \\
\hline PRU -> USS & 0.03 & 0.01 & 0.26 & 0.12 & 0.90 & Not supported \\
\hline SVQ -> PEU & 0.02 & 0.03 & 0.07 & 0.26 & 0.80 & Not supported \\
\hline SVQ -> PRU & 0.39 & 0.40 & 0.08 & 5.13 & 0.00 & Supported \\
\hline SYQ -> PEU & 0.89 & 0.88 & 0.04 & 23.57 & 0.00 & Supported \\
\hline SYQ -> PRU & 0.53 & 0.54 & 0.16 & 3.37 & 0.00 & Supported \\
\hline
\end{tabular}

\section{FINDINGS AND DISCUSSIONS}

The findings have led to implications in the form of suggestions to the technology managers of the digital library in Higher Education in general, and to the technology managers of Higher Education in Kuwait in particular.

1. This research has mainly focussed on dimensions which can be integrated to the Technology Acceptance Model (TAM) in the context of digital library adoption in higher education. The literature review had clearly indicated that the important integration to TAM was through the dimensions - information quality, system quality and service quality. The information quality becomes a significant dimension in the acceptance of technology used in the digital library, as they depend to a great deal on the quality information that is available which facilitated their search and screening of the articles they are looking for through their search strings and key words. System quality also plays a vital role as there should be effective systems which are well integrated with each other and facilitate the operational ease and save 
time to the students while they seek information on a topic of their interest. Service quality is the third important dimension which is necessary for the success of any technology specifically in terms of the stated and implied needs of the customers.

2. Hypothesis testing has revealed that the intention to use (INU) the system has significant positive influence on user satisfaction (USS). This result corroborates well with earlier research studies in various our contexts of technology usage (e.g., Keni, 2020; Chen \& Aklikokou, 2020; Kim \& Lee, 2014; Kurniasari et al., 2020). This indicates that in the context of digital library to enhance the user satisfaction it is necessary to promote the intention to use the technological system of the digital library.

3. The perceived ease of use (PEU) has a positive significant relationship with perceived usefulness (PRU), which in turn has a significant relationship with intention to use (INU) of the technology used in digital library; however, PEU has no significant impact on the user satisfaction (USS). These findings are in alignment with that of a group of earlier researchers (e.g., Caffaro et al., 2020; Chen \& Aklikokou, 2020; Iriani \& Andjarwati, 2020; Winata et al., 2020), but are in contradiction to the findings of another group of researchers (Danurdoro \& Wulandari, 2016; Hamid et al., 2016). One of the reasons for this could be that these studies were in different contexts of technology usage as well as on different geographic locations. It is important to note that even though PEU has no significant relationship with USS, it does have and a relationship with PRU, which in turn has a relationship with INU, and further INU has a significant positive relationship with the USS, and hence, the PEU cannot be ignored, as it indirectly contributes to the USS through the PRU despite the fact that it has no influence on USS.

4. The research revealed that among the three quality dimensions chosen in this research, the system quality has been considered to be the most important dimension by the students of Higher Education as it has a significant positive relationship with both PEU and PRU. Despite the fact that PRU has no significant relationship with the INU, it does affect both the components of TAM. The theoretical model also indicates that INQ has a significant positive relationship with the PRU and SVQ on the PEU as observed by other researchers in many different contexts (e.g., Almahamid et al., 2010; Pitafi et al., 2020; Rahmi, 2018; Kang \& Namkung, 2019; Oliveira et al., 2020).

5. On the overall basis, the critical path of relationship flows from system quality - perceived ease of use intention to use - user satisfaction. This relationships has been endorsed by several researchers in many different contexts(e.g., Almahamid et al., 2010; Pitafi et al., 2020; Rahmi, 2018; Venkatesh, 2010; Fagan et al., 2008; Rawashdeh, 2021; Kim \& Lee, 2014; Kurniasari et al., 2020). Thus, among the three antecedents to TAM the INQ and SYQ can be considered to be the two critical dimensions of quality in the case of digital library, because they can lead to user satisfaction.

\section{THEORETICAL IMPLICATIONS}

The Technology Acceptance Model (TAM) has been severely criticised for its over emphasis on cognitive aspects and lack in consideration towards the emotional, social, human, and psychological aspects of behaviour (Kulviwat et al., 2007; Read et al., 2011). This research has integrated the quality aspects to the TAM for the use in the context of digital library. Based on the empirical analysis a theoretical model is developed (Figure 4), which is specific to the context of technology use in digital library in the Higher Education. This model can be used by the academicians and practitioners to in the field to theorize the antecedents of user satisfaction of the students of Higher Education in connection to the technology usage in digital library. It opens up immense scope for further testing, validating and developing the model in other contexts of geographical locations.

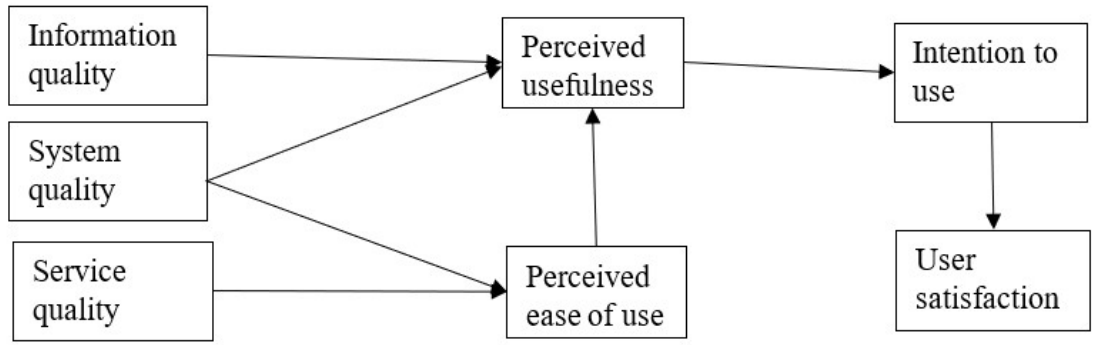

Figure 4: Extended Technology Acceptance Model (ETAM)

\section{PRACTICAL IMPLICATIONS}

Identification of the Antecedents of user satisfaction in the technology adopted in digital library in higher education play a significant role in drawing implications to the technology managers to fine-tune the critical factors in order to make the technology usage more effective. The theoretical model developed in this research through empirical validation based on real-time data has immense practical value which is discussed in the following 
paragraphs.

First of all, it has been found through the hypothesis testing that among the three quality components integrated to the TAM dimensions, the system quality has emerged out to be critical in terms of user satisfaction as it has a significant positive relationship with both the perceived ease of use and perceived usefulness. The perceived ease of use is found to have a significant positive relationship with intention to use the digital library, which in turn impacts the user satisfaction; thus, it is evident that system quality has to be at its best to enhance user satisfaction. Several researchers have commented on the practical value of system quality and suggested measures to improve it. System quality of the technology used in digital library is mainly the IT system quality and this calls for the Chief Information Officers (CIOs) to devise strategies which can enhance the capabilities of the information systems. In the context of the digital libraries the most important aspect which the CIOs should focus on strategizing is the systems that can identify the large chunk of old, irrelevant and outdated information which may pop-up while the students access the digital library. Process Capability Maturity Model (PCMM) (Gorla et al., 2010) has been very successfully used in the software industries but is yet to be implemented in universities and a move in this direction is strongly recommended.

The hypothesis testing has revealed that information quality has a significant positive relationship with perceived usefulness. Even though the perceived usefulness has no significant relationship with either intention to use or user satisfaction, it has an indirect relationship with the intention to use through the perceived usefulness about the digital library so it is important on the part of the students as unless they find it useful they may not use the library frequently. So, the CIOs must also look into the measures to improve information quality (i.e., quality of reports and information in the online screen), which is mainly in terms of keeping the digital content free from data errors, interface issues, fragmented software module etc. The CIOs must also take special care to showcase the internal resources of the universities in the digital library which would be of special interest to the students. The most critical aspect in the enhancement of information quality is the efficiency and effectiveness of the applications which are available in the digital library which are related to information and knowledge tracing, identifying, sorting, retrieving, and storing. A special attention may be required to these aspects to ensure that the information quality of the digital library meets the customer expectations.

Service quality is found to have a positive and significant relationship with perceived ease of use of the digital library technology as per the results of the hypothesis testing. However, it has no relationship with either intention to use or usefulness. Again, as in the previous case even though the service quality does not have a direct relationship either with intention to use of user satisfaction with the digital library, the perceived ease of use becomes important, as it is mediated through the perceived usefulness to the intention to use. It is important that the CIOs take measures to improve the responsiveness, tangibility, and reliability aspects of the applications in the digital library.

\section{CONCLUSION}

This research is very timely in the sense that digital libraries have replaced the conventional hard-copy type of libraries in the modern universities and there is a need to elicit information about the acceptance of this mode of library access by the students so that policy decisions may be made by the technology managers to enhance its effectiveness. Kuwait is one of the GCC countries which has invested a huge amount of money and human resources in multimedia-based learning with digital libraries at the higher educational level (Aljazzaf, 2020; Hammad et al., 2020). So, all the stakeholders in the higher education are keen on the effectiveness of the digital libraries.

In this research, an attempt has been made to extend the Technology Acceptance Model by considering the impact of three components of quality: information quality, system quality, and service quality, which was the missing element in the model. The proposed model was tested using a sample obtained from the students of higher education in Kuwait for the testing of 11 hypotheses. The result was the Extended Technology Acceptance Model (ETAM) which has empirically proved that system quality is the most critical among the three components considered as its impact is on both the perceived ease of use as well as perceived usefulness and this has been the basis for drawing the practical implications. The ETAM can act as the basic model to test the effectiveness of technology used in the digital library in the university. Even though it has been developed in the context of Kuwait, it may be tested in other countries with little or no modification.

In this research the data collection is through convenience sampling, and hence, the generalization has its limitations. Nevertheless, the systematic research methodology adopted in this research and the effective use of bootstrapping to extrapolate the data has taken the measure to compensate for this limitation to the extent possible. Future researchers may adopt the probability based sampling methods to make this research more robust and the ETAM can be tested further and newer variables may be added if they are relevant. This research is purely quantitative as it is basically an empirical study and there is scope to extend the research further by adopting mixed methods approach. Finally, all the generalizations are based on the data collected in Kuwait and the model may have to be tested across the different countries to make it more robust. 
If the students make productive use of the digital library system, its purpose stands fulfilled. The ETAM provides the linkages of the user satisfaction with the digital library, while theoretical implications add to the body of knowledge, the practical implications can be made use of by the CIOs of digital libraries. In a country like Kuwait, the use of digital library learning is relatively new in comparison to the western countries and a research of this nature may pave the way to success of innovative pedagogies.

\section{REFERENCES}

Abdullah, D., Jayaraman, K., Shariff, D. N., Bahari, K. A., \& Nor, N. M. (2017). The effects of perceived interactivity, perceived ease of use and perceived usefulness on online hotel booking intention: A conceptual framework. International Academic Research Journal of Social Science, 3(1), 16-23.

Ajzen, I. (2015). The theory of planned behaviour is alive and well, and not ready to retire: a commentary on Sniehotta, Presseau, and Araújo-Soares. Health psychology review, 9(2), 131-137.

Akar, S. G. M. (2019). Does it matter being innovative: Teachers' technology acceptance. Education and Information Technologies, 24(6), 3415-3432.

Aljazzaf, Z. (2020). Factors Influencing the Use of Multimedia Technologies in Teaching English Language in Kuwait. International Journal of Emerging Technologies in Learning (iJET), 15(5), 212-234.

Almahamid, S. O. U. D., Mcadams, A. C., Al Kalaldeh, T. A. H. E. R., \& Motaz, A. S. E. (2010). The relationship between perceived usefulness, perceived ease of use, perceived information quality, and intention to use egovernment. Journal of Theoretical \& Applied Information Technology, 11(2), 2-38.

Almahamid, S. O. U. D., Mcadams, A. C., Al Kalaldeh, T. A. H. E. R., \& MO'TAZ, A. S. E. (2010). The relationship between perceived usefulness, perceived ease of use, perceived information quality, and intention to use e-government. Journal of Theoretical \& Applied Information Technology, 11I(1), 23-38.

Al-Okaily, M., Alqudah, H., Matar, A., Lutfi, A., \& Taamneh, A. (2020). Dataset on the Acceptance of e-learning System among Universities Students' under the COVID-19 Pandemic Conditions. Data in brief, 32(1), 1-5.

Al-Okaily, M., Alqudah, H., Matar, A., Lutfi, A., \& Taamneh, A. (2020). Dataset on the Acceptance of e-learning System among Universities Students' under the COVID-19 Pandemic Conditions. Data in brief, 32(1), 1-5.

Alsabawy, A. Y., Cater-Steel, A., \& Soar, J. (2016). Determinants of perceived usefulness of e-learning systems. Computers in Human Behavior, 64, 843-858.

Alyoussef, I. Y. (2021). E-Learning Acceptance: The Role of Task-Technology Fit as Sustainability in Higher Education. In Sustainability (Vol. 13, Issue 11). https://doi.org/10.3390/su13116450.

Ameen, N., Willis, R., Abdullah, M. N., \& Shah, M. (2019). Towards the successful integration of e - learning systems in higher education in Iraq: A student perspective. British Journal of Educational Technology, 50(3), 1434-1446.

Andarwati, M., Zuhroh, D., \& Amrullah, F. (2020). Determinants of perceived usefulness and end-user accounting information system in SMEs. International Journal of Advanced Science and Technology, 29(8), 46-61.

Ardiansah, M., Chariri, A., Rahardja, S., \& Udin, U. (2020). The effect of electronic payments security on ecommerce consumer perception: An extended model of technology acceptance. Management Science Letters, 10(7), 1473-1480.

Arta, T. L. F., \& Azizah, S. N. (2020). Pengaruh Perceived Usefulness, Perceived Ease Of Use dan E-Service Quality Terhadap Keputusan Menggunakan Fitur Go-Food dalam Aplikasi Gojek. Jurnal Ilmiah Mahasiswa Manajemen, Bisnis Dan Akuntansi (JIMMBA), 2(2), 291-303.

Boyer, K. K., \& Frohlich, M. (2009). Analysis of Effects of Operational Execution on Repeat Purchasing for Heterogeneous Customer Segments. Production and Operations Management, 15, 229-242.

Bradley, J., \& Lee, C. C. (2007). ERP training and user satisfaction: A case study. International Journal of Enterprise Information Systems (IJEIS), 3(4), 33-50.

Caffaro, F., Cremasco, M. M., Roccato, M., \& Cavallo, E. (2020). Drivers of farmers' intention to adopt technological innovations in Italy: The role of information sources, perceived usefulness, and perceived ease of use. Journal of Rural Studies, 76, 264-271.

Calisir, F., \& Calisir, F. (2004). The relation of interface usability characteristics, perceived usefulness, and perceived ease of use to end-user satisfaction with enterprise resource planning (ERP) systems. Computers in human behavior, 20(4), 505-515.

Chen, L., \& Aklikokou, A. K. (2020). Determinants of E-government adoption: Testing the mediating effects of perceived usefulness and perceived ease of use. International Journal of Public Administration, 43(10), 850865.

Chen, L., \& Aklikokou, A. K. (2020). Determinants of E-government adoption: Testing the mediating effects of perceived usefulness and perceived ease of use. International Journal of Public Administration, 43(10), 850865 .

Chintalapati, N., \& Daruri, V. S. K. (2017). Examining the use of YouTube as a Learning Resource in higher education: Scale development and validation of TAM model. Telematics and Informatics, 34(6), 853-860. 
Danurdoro, K., \& Wulandari, D. (2016). The Impact of perceived usefulness, perceived ease of use, subjective norm, and experience toward student's intention to use internet banking. Jurnal Ekonomi dan Studi Pembangunan, 8(1), 17-22.

Danurdoro, K., \& Wulandari, D. (2016). The Impact of perceived usefulness, perceived ease of use, subjective norm, and experience toward student's intention to use internet banking. Jurnal Ekonomi dan Studi Pembangunan, 8(1), 17-22.

Daryanto, D., Rina, F., Massus, S., \& Siswantari, S. (2019, December). Effect of perceived ease of use of ICT on stakeholder service quality in Vocational High School in West Java. In Journal of Physics: Conference Series (Vol. 1402, No. 7, p. 077079). IOP Publishing.

Davis, F. D. (1989). Perceived usefulness, perceived ease of use, and user acceptance of information technology. MIS quarterly, 319-340.

Dearing, J. W., \& Cox, J. G. (2018). Diffusion of innovations theory, principles, and practice. Health Affairs, 37(2), 183-190.

Dobricki, M., Kim, K. G., Coppi, A. E., Dillenbourg, P., \& Cattaneo, A. (2021). Perceived educational usefulness of a virtual-reality work situation depends on the spatial human-environment relation. Research in Learning Technology, 29(1), 1-11.

Elkaseh, A. M., Wong, K. W., \& Fung, C. C. (2016). Perceived ease of use and perceived usefulness of social media for e-learning in Libyan higher education: A structural equation modeling analysis. International Journal of Information and Education Technology, 6(3), 192.

Fadelelmoula, A. A. (2018). The impacts of the quality dimensions of the ERP system on the realization of the fundamental business objectives and perceived usefulness. International Journal of Enterprise Information Systems (IJEIS), 14(4), 89-107.

Fagan, M. H., Neill, S., \& Wooldridge, B. R. (2008). Exploring the intention to use computers: An empirical investigation of the role of intrinsic motivation, extrinsic motivation, and perceived ease of use. Journal of Computer Information Systems, 48(3), 31-37.

Fathema, N., Shannon, D., \& Ross, M. (2015). Expanding the Technology Acceptance Model (TAM) to examine faculty use of Learning Management Systems (LMSs) in higher education institutions. Journal of Online Learning \& Teaching, 11(2).

Gorla, N., Somers, T. M., \& Wong, B. (2010). Organizational impact of system quality, information quality, and service quality. The Journal of Strategic Information Systems, 19(3), 207-228.

Hamid, A. A., Razak, F. Z. A., Bakar, A. A., \& Abdullah, W. S. W. (2016). The effects of perceived usefulness and perceived ease of use on continuance intention to use e-government. Procedia Economics and Finance, 35(2016), 644-649.

Hamid, A. A., Razak, F. Z. A., Bakar, A. A., \& Abdullah, W. S. W. (2016). The effects of perceived usefulness and perceived ease of use on continuance intention to use e-government. Procedia Economics and Finance, 35(2016), 644-649.

Hammad, S., Graham, T., Dimitriadis, C., \& Taylor, A. (2020). Effects of a successful mathematics classroom framework on students' mathematics self-efficacy, motivation, and achievement: a case study with freshmen students at a university foundation programme in Kuwait. International Journal of Mathematical Education in Science and Technology, 1(1), 1-26.

Hanjaya, S. T., Kenny, S., \& Gunawan, S. S. (2019). Understanding Factors influencing Consumers Online Purchase intention Via Mobile App: Perceived Ease of use, Perceived Usefulness, System Quality, information Quality, and Service Quality. Marketing of Scientific and Research Organizations, 32, 175-205. https://doi.org/10.2478/minib-2019-0035

Iriani, S. S., \& Andjarwati, A. L. (2020). Analysis of perceived usefulness, perceived ease of use, and perceived risk toward online shopping in the era of Covid-19 pandemic. Systematic Reviews in Pharmacy, 11(12), 313 320 .

Ismail, H. A. (2016). Intention to use smartphone through perceived compatibility, perceived usefulness, and perceived ease of use. Jurnal Dinamika Manajemen, 7(1), 1-10.

Japutra, A., Utami, A. F., Molinillo, S., \& Ekaputra, I. A. (2021). Influence of customer application experience and value in use on loyalty toward retailers. Journal of Retailing and Consumer Services, 59(March), 102390. https://doi.org/10.1016/j.jretconser.2020.102390

Kang, J. W., \& Namkung, Y. (2019). The information quality and source credibility matter in customers' evaluation toward food O2O commerce. International Journal of Hospitality Management, 78, 189-198.

Kang, J.-W., \& Namkung, Y. (2019). The information quality and source credibility matter in customers' evaluation toward food O2O commerce. International Journal of Hospitality Management, 78, 189-198. https://doi.org/https://doi.org/10.1016/j.ijhm.2018.10.011

Keni, K. (2020). How Perceived Usefulness and Perceived Ease of Use Affecting Intent to Repurchase?. Jurnal Manajemen, 24(3), 481-496. 
Keni, K. (2020). How Perceived Usefulness and Perceived Ease of Use Affecting Intent to Repurchase?. Jurnal Manajemen, 24(3), 481-496.

Kim, H.-W., Xu, Y., \& Koh, J. (2004). A Comparison of Online Trust Building Factors between Potential Customers and Repeat Customers. J. AIS, 5. https://doi.org/10.17705/1jais.0005.

Kim, Y., \& Lee, H. S. (2014). Quality, perceived usefulness, user satisfaction, and intention to use: An empirical study of ubiquitous personal robot service. Asian Social Science, 10(11), 1-8.

Klopping, I. M., \& McKinney, E. (2004). Extending the technology acceptance model and the task-technology fit model to consumer e-commerce. Information Technology, Learning \& Performance Journal, 22(1).

Korhan, O., \& Ersoy, M. (2016). Usability and functionality factors of the social network site application users from the perspective of uses and gratification theory. Quality \& quantity, 50(4), 1799-1816.

Kulviwat, S., Bruner, G.C., Kumar, A., Nasco, S.A., Clark, T., 2007. Toward a unified theory of consumer acceptance technology. Psychology and Marketing 24 (12), 1059-1084.

Kurniasari, F., Abd Hamid, N., \& Qinghui, C. (2020). The Effect Of Perceived Usefulness, Perceived Ease Of Use, Trust, Attitude And Satisfaction Into Continuance Intention In Using Alipay. Management \& Accounting Review (MAR), 19(2).

Lavidas, K., Achriani, A., Athanassopoulos, S., Messinis, I., \& Kotsiantis, S. (2019). University Students' intention to use search engines for research purposes: a structural equation modeling approach. Education and Information Technologies, 1-17.

Lee, J., Kim, J., \& Choi, J. Y. (2019). The adoption of virtual reality devices: The technology acceptance model integrating enjoyment, social interaction, and strength of the social ties. Telematics and Informatics, 39, 3748. https://doi.org/https://doi.org/10.1016/j.tele.2018.12.006

Lee, S., \& Kim, B. G. (2009). Factors affecting the usage of intranet: A confirmatory study. Computers in Human Behavior, 25(1), 191-201.

Lin, H. F. (2006). Understanding the behavioural intention to participate in virtual communities. CyberPsychology \& Behavior, 9(5), 540-547.

Liu, S., \& Napitupulu, T. A. (2020). Analyzing factors affecting satisfaction and purchase intention towards mobile augmented reality e-commerce applications in Indonesia. Journal of Theoretical and Applied Information Technology, 98, 3503-3517

Martín - García, A. V., Martínez - Abad, F., \& Reyes - González, D. (2019). TAM and stages of adoption of blended learning in higher education by application of data mining techniques. British Journal of Educational Technology, 50(5), 2484-2500.

McKinney, V., Yoon, K., \& Zahedi, F. (2002). The Measurement of Web-Customer Satisfaction: An Expectation and Disconfirmation Approach. Information Systems Research, 13, 296-315. https://doi.org/10.1287/isre.13.3.296.76

Mican, D., Sitar-Tăut, D. A., \& Moisescu, O. I. (2020). Perceived usefulness: A silver bullet to assure user data availability for online recommendation systems. Decision Support Systems, 139, 113420.

Normelindasari, D., \& Solichin, A. (2020, February). Effect of system quality, information quality, and perceived usefulness on user satisfaction of webstudent applications to improve service quality for Budi Luhur University Students. In Proceedings of the 4th International Conference on Management, Economics and Business (ICMEB 2019). Paris, France: Atlantis Press. https://doi. org/10.2991/aebmr. k (Vol. 200205).

Oliveira, R. D. C., Baldam, E. C. G. D. R., Costa, F. R. D., \& Pelissari, A. S. (2020). The effect of perceived usefulness of online reviews on hotel booking intentions. Revista Brasileira de Pesquisa em Turismo, 14, 3045.

Pitafi, A. H., Kanwal, S., \& Khan, A. N. (2020). Effects of perceived ease of use on SNSs-addiction through psychological dependence, habit: The moderating role of perceived usefulness. International Journal of Business Information Systems, 33(3), 383-407.

Pozón-López, I., Kalinic, Z., Higueras-Castillo, E., \& Liébana-Cabanillas, F. (2020). A multi-analytical approach to modeling of customer satisfaction and intention to use in Massive Open Online Courses (MOOC). Interactive Learning Environments, 28(8), 1003-1021.

Rafique, H., Almagrabi, A. O., Shamim, A., Anwar, F., \& Bashir, A. K. (2020). Investigating the acceptance of mobile library applications with an extended technology acceptance model (TAM). Computers \& Education, 145, 103732.

Rahmi, B. A. K. I., Birgoren, B., \& Aktepe, A. (2018). A meta analysis of factors affecting perceived usefulness and perceived ease of use in the adoption of e-learning systems. Turkish Online Journal of Distance Education, 19(4), 4-42.

Rawashdeh, A. M., Elayan, M. B., Alhyasat, W., \& Shamout, M. D. (2021). Electronic Human Resources Management Perceived Usefulness, Perceived Ease Of Use And Continuance Usage Intention: The Mediating Role Of User Satisfaction In Jordanian Hotels Sector. International Journal for Quality Research, 15(2), 3846. 
Read, W., Robertson, N., \& McQuilken, L. (2011). A novel romance: the technology acceptance model with emotional attachment. Australasian marketing journal (AMJ), 19(4), 223-229.

Rita, P., Oliveira, T., \& Farisa, A. (2019). The impact of e-service quality and customer satisfaction on customer $\begin{array}{lllll}\text { behavior in } & \text { online } 02690 .\end{array}$ https://doi.org/https://doi.org/10.1016/j.heliyon.2019.e02690

Ruggieri, S., Bonfanti, R. C., Passanisi, A., Pace, U., \& Schimmenti, A. (2021). Electronic surveillance in the couple: The role of self-efficacy and commitment. Computers in Human Behavior, 114, 106577.

Saadé, R., \& Bahli, B. (2005). The impact of cognitive absorption on perceived usefulness and perceived ease of use in on-line learning: an extension of the technology acceptance model. Information \& management, 42(2), 317-327.

Suki, N. M., \& Suki, N. M. (2011). Exploring the relationship between perceived usefulness, perceived ease of use, perceived enjoyment, attitude and subscribers' intention towards using $3 \mathrm{G}$ mobile services. Journal of Information Technology Management, 22(1), 1-7.

Tahar, A., Riyadh, H. A., Sofyani, H., \& Purnomo, W. E. (2020). Perceived ease of use, perceived usefulness, perceived security and intention to use e-filing: The role of technology readiness. The Journal of Asian Finance, Economics, and Business, 7(9), 537-547.

Valencia, D. C., Alejandro, V. A., Bran, L., Benjumea, M., \& Valencia, J. (2019). Analysis of e-commerce acceptance using the technology acceptance model. In Scientific papers of the University of Pardubice. Series D, Faculty of Economics and Administration (Vol. 45).

Venkatesh, V. (2000). Determinants of perceived ease of use: Integrating control, intrinsic motivation, and emotion into the technology acceptance model. Information systems research, 11(4), 342-365.

Venkatesh, V., Thong, J. Y., \& Xu, X. (2016). Unified theory of acceptance and use of technology: A synthesis and the road ahead. Journal of the association for Information Systems, 17(5), 328-376.

Walsh, G., \& Beatty, S. (2007). Customer-Based Corporate Reputation of a Service Firm: Scale Development and Validation. Journal of the Academy of Marketing Science, 35, 127-143. https://doi.org/10.1007/s11747-007$\underline{0015-7 .}$.

Wan, C., \& Shen, G. Q. (2015). Encouraging the use of urban green space: The mediating role of attitude, perceived usefulness and perceived behavioural control. Habitat International, 50, 130-139.

Wang, P., \& Li, H. (2019). Understanding the antecedents and consequences of the perceived usefulness of travel review websites. International Journal of Contemporary Hospitality Management, 31(3), 1086-1103. https://doi.org/10.1108/IJCHM-06-2017-0380

Wang, Y., Wang, S., Wang, J., Wei, J., \& Wang, C. (2020). An empirical study of consumers' intention to use ride-sharing services: using an extended technology acceptance model. Transportation, 47(1), 397-415.

Wicaksono, A., \& Maharani, A. (2020). The Effect of Perceived Usefulness and Perceived Ease of Use on the Technology Acceptance Model to Use Online Travel Agency. Journal of Business Management Review, 1(5), 313-328.

Winata, L., Permana, D., No, J. M. S., \& Indonesia, J. B. (2020). The effect of electronic coupon value to perceived usefulness and perceived ease-of-use and its implication to behavioral intention to use server-based electronic money. International Journal of Innovative Science and Research Technology, 5(1), 147-158. 
Appendix 1: Questionnaire used in Extended Technology Acceptance Model
Digital library User Satisfaction in Higher Education

Name: Personal Data (Optional)

Institution:

Email:

Contact number:

\section{About this Research}

Dear Respondent,

Thank you for taking part in this research. This questionnaire contains questions about your experience with using digital library as an add-on to your learning. Kindly share your experiences in using the digital library. The information is quite valuable to us and it will be used for research purposes and the recommendations we make will help improve the user satisfaction.

\section{Confidentiality Statement}

The data in the questionnaire shall be used solely for academic research purpose. You don't have to disclose your identity and even if disclosed it will not be used anywhere.

\section{Questions}

If you require assistance in completing this questionnaire or have any questions regarding the survey, please contact:

Dr. Rabab Dawoud Alsaffar PhD (University of York, UK)

The Public Authority for Applied Education \& Training,

Ph: +965 9955 1007; rd.alsaffar@paaet.edu.kw

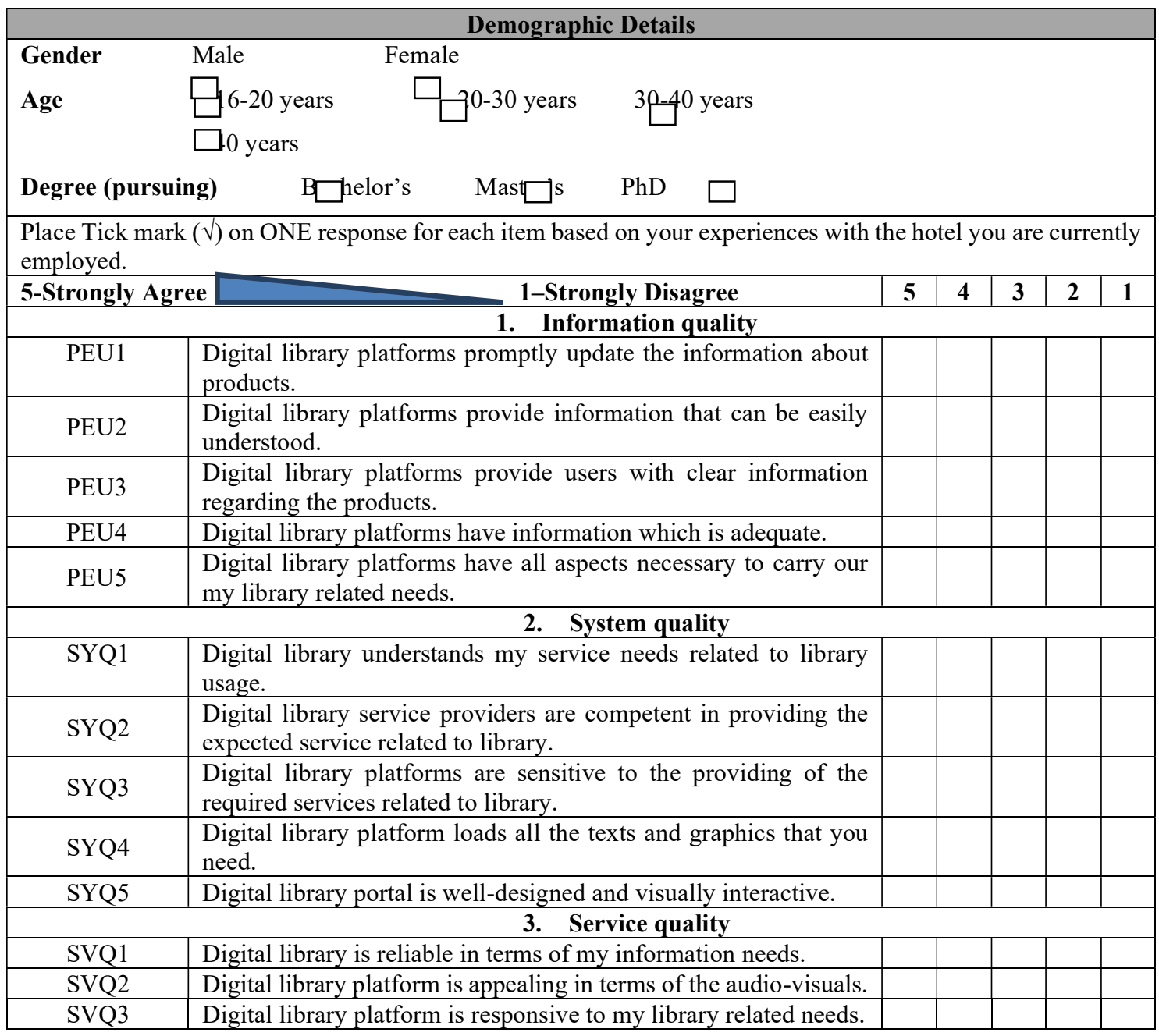




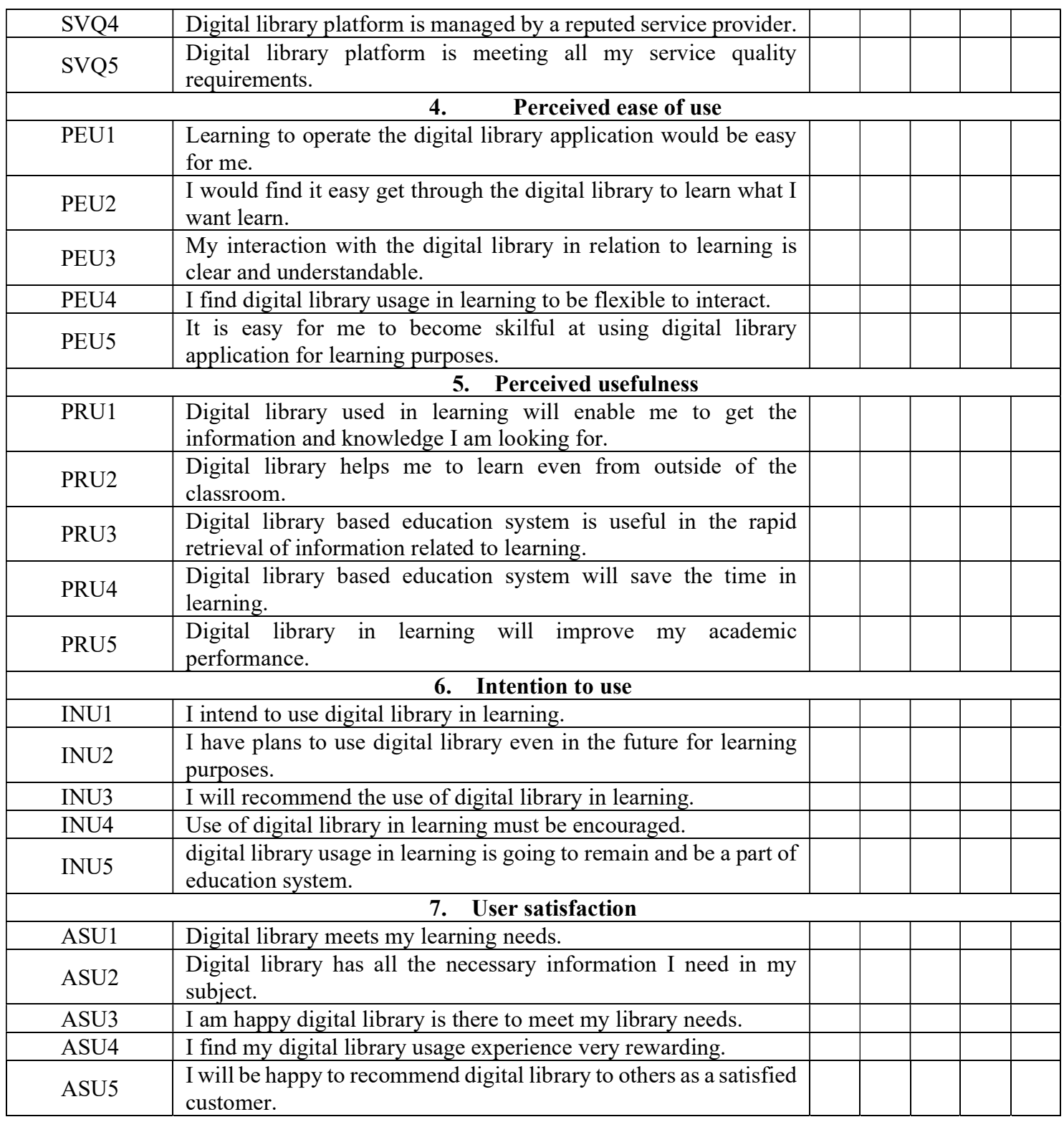

Thank you for your participation.

\section{Dr. Rabab Dawoud Alsaffar}

